\title{
Environmental cycles in the late Jurassic northwest European epeiric basin: interaction with atmospheric and hydrospheric circulations
}

\author{
Wolfgang Oschmann \\ Institut für Paläontologie Universität Würzburg, Pleicherwall 1, D-8700 Würzburg (F.R.G.)
}

Received January 2, 1990; revised and accepted August 16, 1990

\begin{abstract}
Oschmann, W., 1990. Environmental cycles in the late Jurassic northwest European epeiric basin: interaction with atmospheric and hydrospheric circulations. In: T. Aigner and R.H. Dott (Editors), Processes and Patterns in Epeiric Basins. Sediment. Geol., 69: 313-332.

Despite the large size and the heterogeneity of the northwest European late Jurassic (Kimmeridgian/Lower Tithonian) epeiric basin the sedimentary environment was rather uniform. In general, deposition of mudstones and the microlaminated organic-rich sediments took place under low-oxic to anoxic conditions.

Detailed environmental analysis clearly points to a seasonal alternation of aerobic with anaerobic conditions in substrate and bottom water, resulting in one year life-cycles in the benthic environment.

The widespread uniformity of facies and the seasonal alternation in the oxygen budget of the benthic environments are best explained by a summer to winter change in the atmospheric circulation of the Northern Hemisphere. This change strongly influenced the oceanographic situation in the northwestern European epeiric basin. Superposed on this one-year cyclicity, three more hierarchical levels of cycles are stratigraphically recorded. They reflect a complex history of orbital-forced, and non-orbital-forced climatic changes and/or eustatic sea-level fluctuations in the late Jurassic.
\end{abstract}

\section{Introduction}

Organic-rich mudstones with thin intercalations of oil shales and coccolith limestones are widespread over vast areas in the late Jurassic (Kimmeridgian/Lower Tithonian). The same facies occurs along a south-north axis of almost $3.000 \mathrm{~km}$ from the English Channel to the Barents Sea (e.g. Cornford, 1986; Gage and Doré, 1986; Doré and Gage, 1987; Oschmann, 1988b; Ziegler, 1988). The basinal parts of the northwestern European Archipelago and the North Atlantic Shelf Sea between Greenland and Baltica, covering about 1 million $\mathrm{km}^{2}$, apparently were affected by low-oxic to anoxic conditions (Fig. 1). Organic geochemical analyses exhibit a striking similarity in molecular characteristics of North Sea and Greenland Kimmeridgian/Tithonian hydrocarbons. They had been generated from very similar organic facies and were deposited under similar environmental conditions (Requejo et al., 1989).

The particular situation of rifting and slow crustal extension, combined with the late Jurassic transgressive peak, led to the establishment of a complex seaway between the Arctic, Central Atlantic, and Tethyan Oceans (e.g. Gage and Doré, 1986; Doré and Gage, 1987; Oschmann, 1988b; Ziegler, 1988).

Recently presented models explain the facies distribution and alternation by topographic lows and highs (Scotchman, 1989) and/or by the influence of storms and overturn of the water column (Wignall, 1989). Both models are important for explaining local to regional variations, but they do not explain the uniformity of the facies on a basin-wide scale. Explanation of the widespread oxygen-controlled "mega-environment" requires the combination of detailed facies and palaeoeco- 

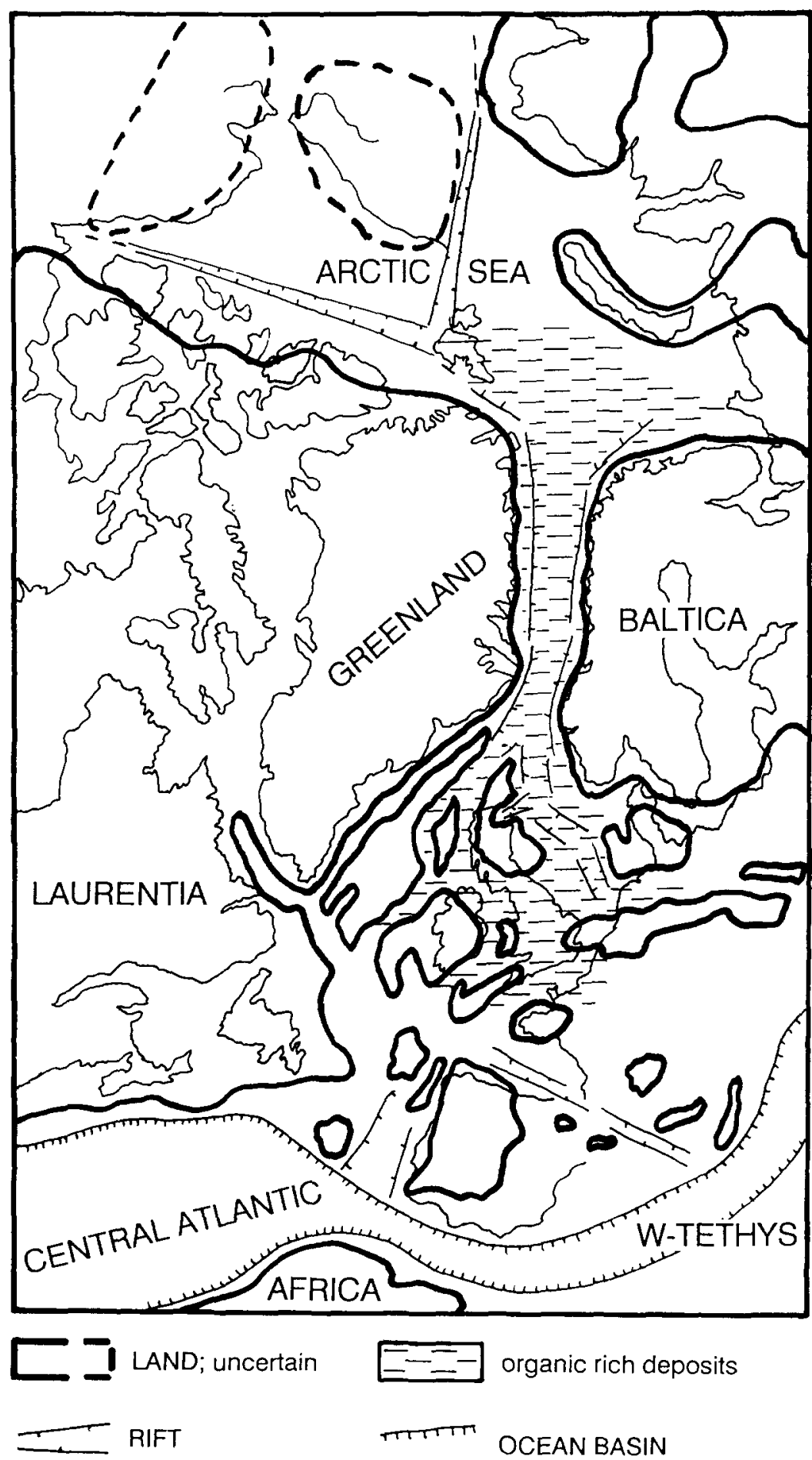

organic rich deposits

OCEAN BASIN

Fig. 1. Late Jurassic (Kimmeridgian/Lower Tithonian) palaeogeographic reconstruction of the Arctic. North Atlantic, northern Central Atlantic and western Tethyan Ocean (modified after: Doré and Gage, 1987; Rowley and Lottes, 1988; Ziegler, 1988). Open marine connections are established between the Central Atlantic, western Tethys and the Arctic Sea. 
logical analysis with global atmospheric and hydrospheric circulation patterns and their seasonal alternation.

\section{Facies distribution and alternation}

Sedimentation of coarse-grained cross-bedded sands and silty sands with abundant body and trace fossils, took place in the coastal environments of the northwestern European Archipelago and the North Atlantic Shelf Sea (e.g. Fürsich, 1982, 1984a, b; Oschmann, 1985, 1988a, b, 1991). In an offshore direction, the lithofacies rapidly changes to uniform fine-grained clastics, which are partly organic-rich and microlaminated. In these basinal parts deposition took place in an environment with a stratified water column and under very quiet, low-oxic to anoxic bottom conditions.

Despite the uniformity of facies in the late Jurassic epeiric basin, lateral and temporal facies variations are notable (Tyson et al., 1979; Wilson, 1980; Cox and Gallois, 1981; Oschmann, 1985, 1988a, b, 1990, 1991; Wignall and Myers, 1988; Wignall, 1989; Scotchman, 1989). These variations result from changes in water depth and basin morphology, respectively, that may have ranged from 50 to $100 \mathrm{~m}$ in southern England to a few hundred metres in the graben systems (Ziegler, 1982, 1988; Oschmann, 1985, 1988b), and to other local to regional factors such as sediment supply, storms, rift vulcanism or earthquakes.

For modelling the benthic environment on the base of sedimentological and palaeoecological data, two sets of factors must be considered. Firstly, the primary factors, e.g. occurrence and taphonomy of the benthic fauna, bioturbation, amount of organic matter (TOC) and the microlamination (Fig. 2). The latter indicates not only very quiet environmental conditions but also points to a short-term alternation in predominance of terrigenous sediment supply and predominance of plankton productivity (Fig. 3). The second set of factors are those that modified or blurred the primary ones, such as small-scale slumping and re-deposition as graded rip-up casts (Fig. 4 ). They were used to claim a strong regional morphology (Scotchman, 1989) and/or regular storm mixing and overturn in the water column (Wignall, 1989), which is thought to provide oxygen to the benthic environment. Without any doubt, the features indicate that, but are they really significant? The preservation potential of
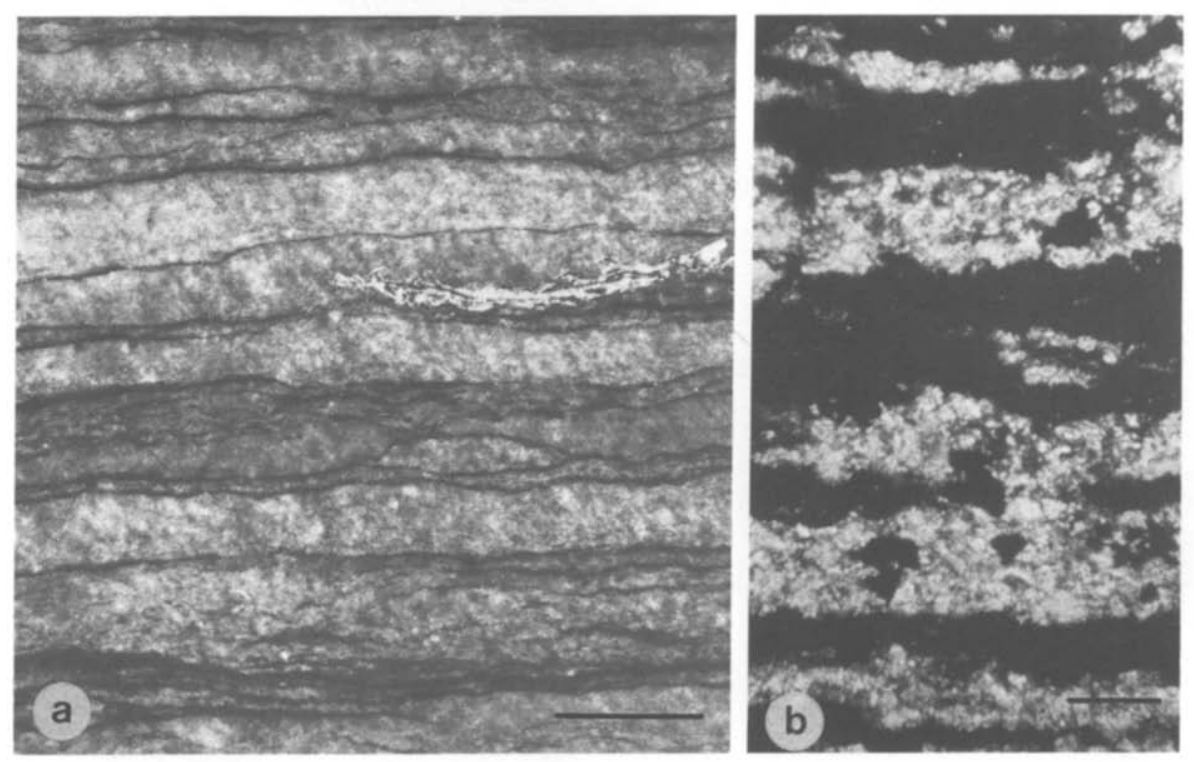

Fig. 2. Microlaminations are a conspicuous feature in the poikiloaerobic zone and even more in the anaerobic zone. They indicate very quiet environmental conditions and an alternation of terrigenous sediment supply and plankton productivity. (a) Polished section with well preserved microlamination (black layers $0.1 \mathrm{~mm}$, white layers $0.5-1 \mathrm{~mm}$, scale bar $2 \mathrm{~mm}$ ). (b) Thin section of the microlamination. Dark laminae consist of clay minerals and organic material, white laminae of sparry calcite (scale bar $0.1 \mathrm{~mm}$ ). 

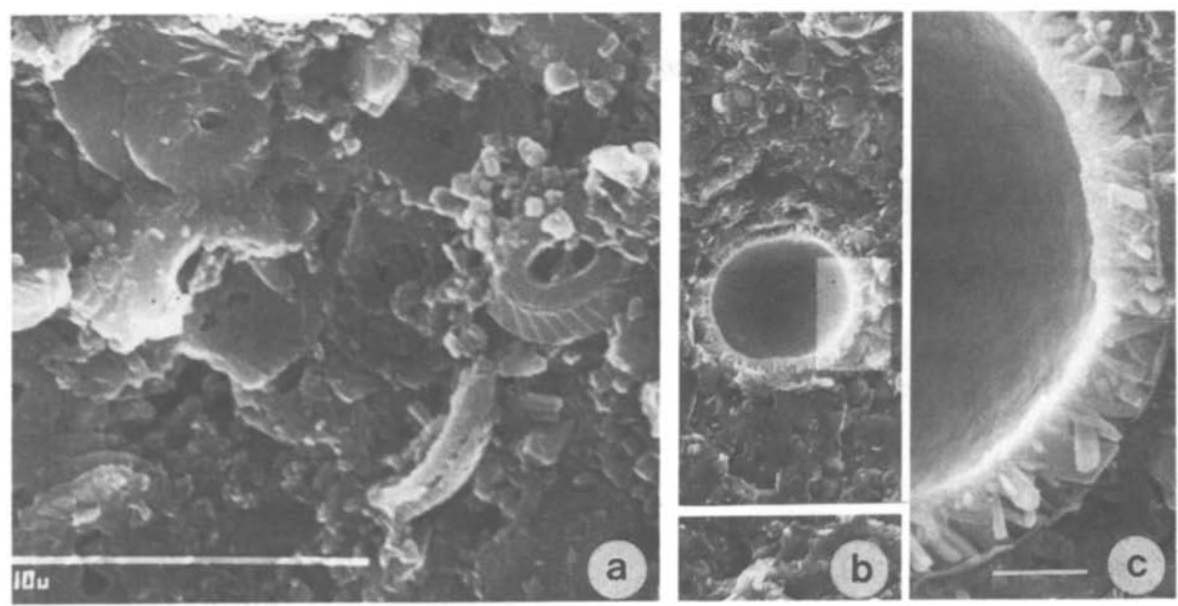

Fig. 3. Close-up of white lamina showing an irregular fabric of rock-forming coccoliths which originated from phytoplankton blooms in surface waters: (a) dominantly ellipsagelosherids; (b) and (c) calcispheres (Obliquipithonella multistriata). Scale bars resp. $10 \mu \mathrm{m}$, $50 \mu \mathrm{m}$, and $5 \mu \mathrm{m}$ ).

the quiet water microlamination is much lower than that of the slumps and tempestites. Nevertheless, parts of the sections are very well microlaminated, and beds with partly disturbed microlaminations still indicate long periods of quiet depositional conditions. Less distinct microlamination commonly is caused by deposition of pellets, which are larger in size than the thicknesses of single laminae (Fig. 5). But, still the environmental conditions had been very quiet. The percentage of disturbed beds with graded rip-up clasts or tempestites is low (e.g. Oschmann, 1988b), indicating a long time-span (perhaps in the order of hundreds or even thousands of years) between successive storm events. Environmentally the long periods of quiet conditions are much more important than the rare cases of high-energy pulses. In addition, stratified water masses are a surprisingly stable feature. In present-day environments stratification of the water column with anoxic bottom conditions re-established themselves only a few days after a hurricane passed
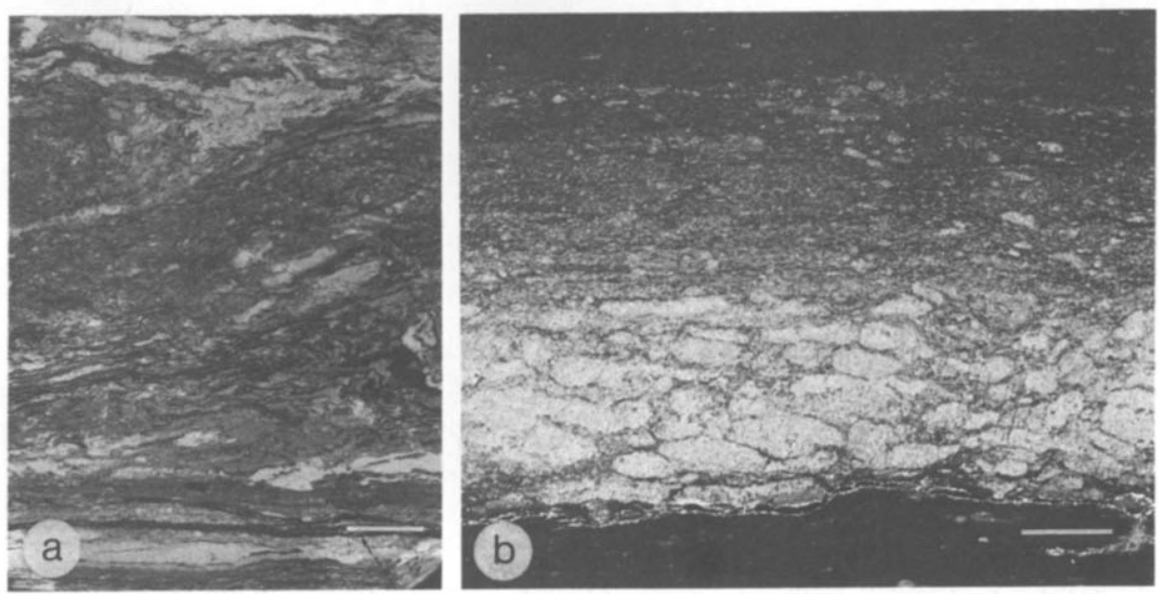

Fig. 4. Gentle tectonic movements and distal storm events occasionally caused disruption of microlamination. They produced small-scale slump structures (a, scale bar $5 \mathrm{~mm}$ ), and reworked and graded rip-up casts on top of an erosive surface (b, scale bar 2 $\mathrm{mm})$. 

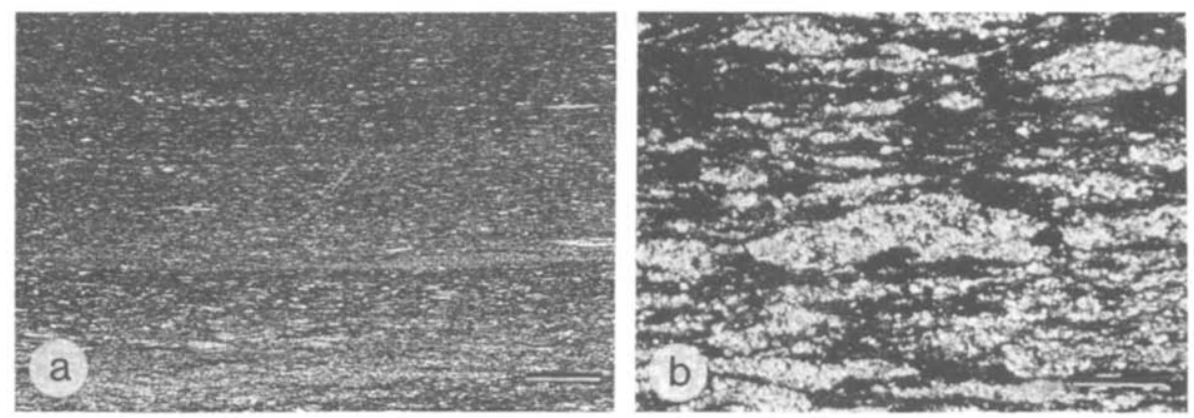

Fig. 5. Pellet deposition cause less distinct microlamination. Calcareous pellets consisting of coccoliths and calcispheres are flattened by compaction and surrounded by clay and organic material; (a) polished section, scale bar $3 \mathrm{~mm}$; (b) thin section, scale bar $0.4 \mathrm{~mm}$.

through (e.g. Steimle and Sindermann, 1978). Reworking of the anoxic sediment enriches $\mathrm{H}_{2} \mathrm{~S}$ in the bottom water, which then becomes even more toxic than before (e.g. Rachor, 1982). Single storm events, such as those indicated by the isolated distal tempestites, were probably not able to oxygenate the benthic environment.

The primary factors, therefore, are thought to be the more reliable environmental indicators and are therefore used to reconstruct the position of the $\mathrm{O}_{2} / \mathrm{H}_{2} \mathrm{~S}$ interface with respect to the depositional interface and to arrange the facies along an oxygen gradient (Fig. 6 ). Three major categories of benthic environments can be distinguished indicating increasingly deteriorating life conditions (for more details see Oschmann, 1988b, 1990, 1991).

\section{Aerobic environments}

In the upper part of the substrate and the bottom-water enough oxygen was present to support a low to moderately diverse benthic fauna. Anoxic conditions, when occurring, were very short. The texture of the substrate is bioturbated to homogeneous due to the activity of soft-bodied and shelly benthic fauna. Although the shelly benthos sometimes form skeletal concentrations indicative of higher-energy pulses, the normal environmental conditions were reasonably quiet. This

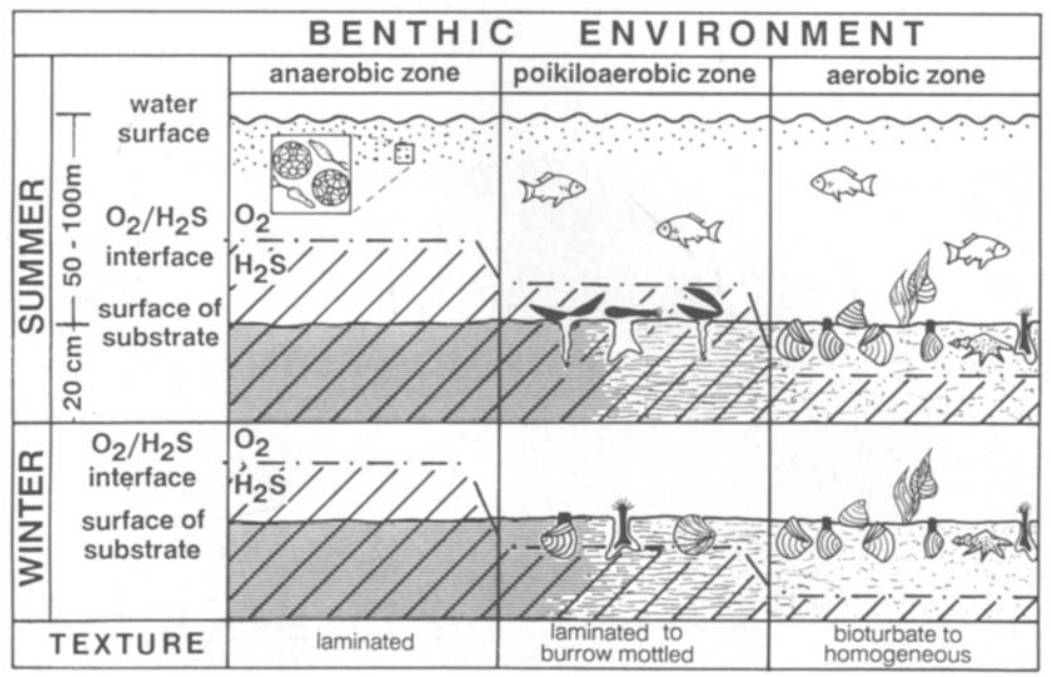

Fig. 6. Schematic facies model for oxygen-deficient settings in the nortwest European epeiric basin. The anaerobic zone generally excluded benthic life based on oxygen. The aerobic zone provided enough oxygen to support a low to moderately diverse benthic fauna. In the poikiloaerobic zone the amount of oxygen fluctuated, depending on season, from well oxygenated to anaerobic (detailed discussion see text). 
is indicated out by autochthonous nested bivalves that sometimes even occur in life position.

\section{Anaerobic environments}

Beside very rare reworked and transported bivalve pavements, no benthic fauna exists. Instead, the sediments, oil shales and coccolith limestones, generally are microlaminated. The microlamination consists of a conspicuous alternation of $0.5-1$ $\mathrm{mm}$ thick light calcite layers and $0.1 \mathrm{~mm}$ thick dark argillaceous layers rich in organic material (Fig. 2). The white layers nearly exclusively consist of coccoliths and rare calcispheres (Fig. 3), but are almost barren of organic matter. Coccoliths consist largely of poly-saccharides, which are highly mobile and easily disintegrated and therefore lost during diagenesis (R. Littke, pers. communication, 1990). Probably parts of the organic matter was then secondarily trapped in the argillaceous layers. The varve-like sedimentation pattern is thought to reflect regularly recurrent surface-water plankton blooms in a stratified water column. The $\mathrm{O}_{2} / \mathrm{H}_{2} \mathrm{~S}$ interface was above the surface of substrate, and excluded all benthic life based on oxygen.

These two categories are in accordance with the classical studies on oxygen-deficient marine environments (e.g. Rhoads and Morse, 1971; Byers, 1977; Savrda et al., 1984; Arthur et al., 1984; Thompson et al., 1985; Kammer et al., 1986). The third category, however, differs markably from the dysaerobic environment of the classical models, which is characterized by low, but stable oxygen values $\left(0.1-0.3 \mathrm{ml} / 1 \mathrm{O}_{2}\right)$. It also differs from the exaerobic environment as defined by Savrda and Bottjer (1987), which is characterized by the symbiotic association of sulphur-oxidizing bacteria with certain bivalves at the anaerobic-dysaerobic transition. Bivalves known to contain chemoautotrophic bacteria in part have reduced or lost their digestive system (e.g. Solemyidae) and occur in deep-sea hydrothermal vent communities, but also in other environments where hydrocarbons are available such as stagnant basins or mangrove swamps (Cary et al., 1988; Seilacher, 1990). This chemosymbiosis requires long term stable conditions with a balanced juxtaposition of oxygen and $\mathrm{H}_{2} \mathrm{~S}$.

\section{Poikiloaerobic environment}

This facies is the key for understanding the dynamics in the oxygen-controlled environments of the Late Jurassic. On the one hand the poikiloaerobic facies (from greek poikilos = variable; details see Oschmann, 1990, 1991) is still microlaminated, indicating very quiet environmental conditions. On the other hand, within the laminae and parallel to bedding planes, loosely packed and patchily distributed bivalve shells occur. All bivalves belong to the shallow burrowing infauna and despite the quiet environmental con-
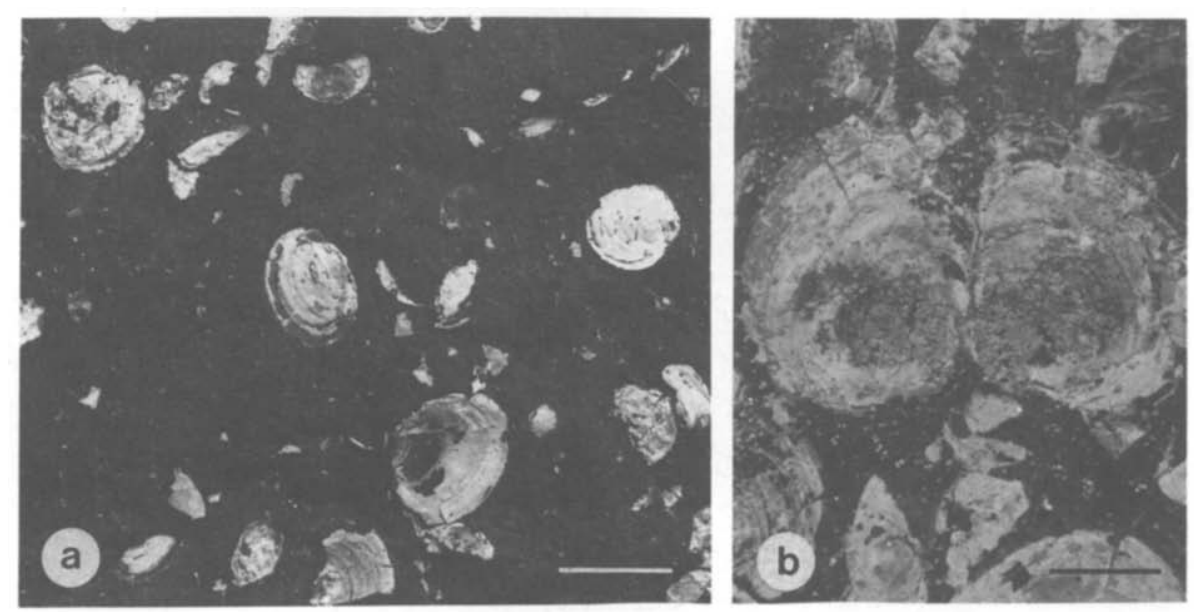

Fig. 7. In the microlaminated poikiloaerobic facies infaunal bivalves occur scattered or in small nests (a). They lack abrasion and are commonly articulated (b) but gapping and invariably parallel to bedding plane (a, scale bar $1 \mathrm{~cm} ; \mathrm{b}, 0.5 \mathrm{~cm}$ ). 
ditions are not preserved in life position. The shells commonly are articulated and lack abrasion (Fig. 7).

This feature is explained analogous to observations in present-day eutrophic shelf environments (Steimle and Sindermann, 1978; Swanson et al., 1979; Dethlefsen and Westernhagen, 1983; Westernhagen and Dethlefsen, 1983; Taylor et al., 1985). During late spring and summer lasting phytoplankton blooms occur, which are associated with oxygen depletion and mass mortality of benthic fauna. Due to oxygen consumption the $\mathrm{O}_{2} / \mathrm{H}_{2} \mathrm{~S}$ interface migrates out of substrate. The mobile endobenthic fauna, such as bivalves, tries to follow the rising interface. As a consequence the dead fauna accumulates on the surface of substrate. This way mud-supported, patchily distributed bivalve shells are generated, which are arranged parallel to bedding planes within microlaminated sediments (Fig. 7).

Bivalve shell accumulations within the poikiloaerobic facies in part were caused by winnowing and reworking (Oschmann, 1985, 1988b; Wignall, 1989). However, they differ remarkably in their grain-supported fabric, preferred convex-up orientation of valves and by the co-occurrence of small erosive sedimentary interfaces and disturbed microlaminations (Fig. 4b). The lack of infaunal bivalves in life position within laminated strata of poikiloaerobic facies suggests that the fauna regularly died from lack of oxygen. On the other hand, continuous presence of benthic fauna in the strata demonstrates that life at the sea-floor was not excluded for longer periods (years, tens of years or longer). Short-term changes in the amount of oxygen and $\mathrm{H}_{2} \mathrm{~S}$ must be assumed. The migration of the $\mathrm{O}_{2} / \mathrm{H}_{2} \mathrm{~S}$ interface between positions below, at, or above the sediment/water interface must have occurred in periods shorter than the life-span of small infaunal bivalves, which lasts at the most a few years. Most probably, the migration of the $\mathrm{O}_{2} / \mathrm{H}_{2} \mathrm{~S}$ interface was an annually recurring feature, caused by phytoplankton blooms during summer lasting some weeks to a maximum of three months.

Survival of the benthos in this harsh environment requires a special reproduction strategy (Oschmann, 1990, 1991). The bivalves have to reach their reproductive age within eight to ten months, to send their planktotrophic larvae to the oxygenated plankton-rich surface waters at the onset of a phytoplankton bloom. There larval development takes place, and lasts from some weeks to 50 days (Sastry, 1979) and enables the larvae to persist unaffected by any lethal bottomwater conditions. Bivalve prodissoconchs, which occur sometimes abundantly on bedding planes (Fig. 8), show that larval swarms tried to settle, but apparently failed owing to extended periods of anoxia. This survival strategy is also corroborated by the fact that all bivalves in the poikiloaerobic facies have a planktotrophic larval development.

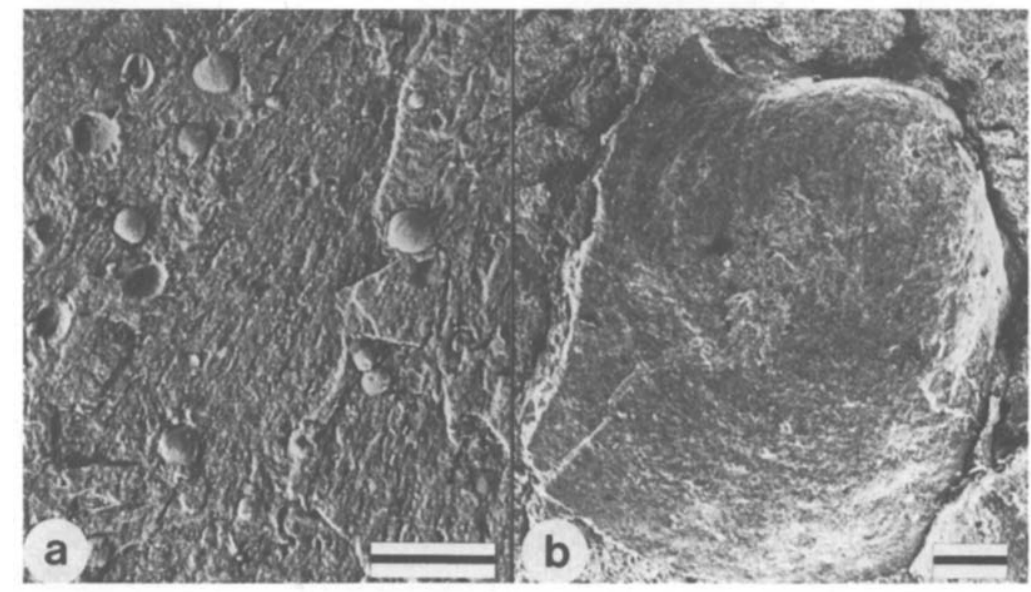

Fig. 8. Bivalve prodissoconchs and small dissoconchs occur sometimes abundantly on bedding planes. They indicate that survival of larvae settling on the sea-floor sometimes failed due to extended periods of anoxia (a, scale bar $2 \mathrm{~mm} ; \mathrm{b}, 100 \mu \mathrm{m}$ ). 
Bivalves with lecithotrophic larvae (such as nuculids) generally are missing. Such larvae develop on the sea-floor, and, like the adults, are not able to endure anoxic periods of some weeks to months duration. In conclusion, the benthic life in the poikiloaerobic facies obviously was bound to a one year cycle.

\section{Late Jurassic climate and the seasonal reversal in the atmosphere's circulation pattern}

Seasonality is probably the most prominent short-term factor controlling the geo- and biosphere (e.g. Valentine, 1983). Nonetheless, this factor commonly is neglected in geological studies. Partly, this may be due to the very low preservation potential of short-term cycles, which easily become blurred or overprinted by events (e.g. storms) or longer-term processes. Moreover, geologists and palaeontologists generally assume optimum resolution in the geological record on the order of some ten thousand to hundred thousand years in the Pre-Quaternary by using Milankovitch cyclicity and biozonation (e.g. Schwarzacher, 1989; Bassett, 1990). Fortunately, in certain settings the particular interplay of sedimentological and palaeoecological parameters permit resolution far beyond the "normal" optimum resolution. The present data for example clearly indicate seasonality in the late Jurassic environments of the northwestern European epeiric basin.

From our present-day experience we know that seasonality is expressed by distinct climatic changes, which, since tilt of the earth axis seems to be a permanent feature (e.g. Parrish, 1982; Parrish and Barron, 1986; Parrish and Spicer, 1988a, b), was also the case during late Jurassic time. Seasonal alternations in the solar insolation create variations in the global atmospheric circulation.

The atmospheric circulation results from a complex interaction of physical and geographical factors (e.g. Parrish and Barron, 1986; Barry and Chorley, 1987). In a homogeneous world (with the same equator-to-pole temperature gradient as today) the hypothetical surface circulations would form a zonal pattern. According to seasons, the zonal circulation pattern would shift poleward on the summer hemisphere (Fig. 9), without strong asymmetry between summer and winter hemispheres. The land-sea thermal contrast and the Coriolis force cause modification or even disruption of the zonal pattern and establishment of quasi-permanent and mobile eddies (Fig. 10). During summer heating low-pressure cells form in low- to mid-latitude continents. In contrast, lowand mid-latitude continents are ruled by highpressure cells during winter. Very prominent during summer, but perennially present are the quasi-permanent subtropical high-pressure cells over the oceans. Depending on the particular palaeogeographic configuration a more or less large-scale seasonal reversal of the wind regime takes place. The circulation pattern then varies between zonal and meridional, commonly also called "monsoonal" (Fig. 10).

Many other factors, which are very complex

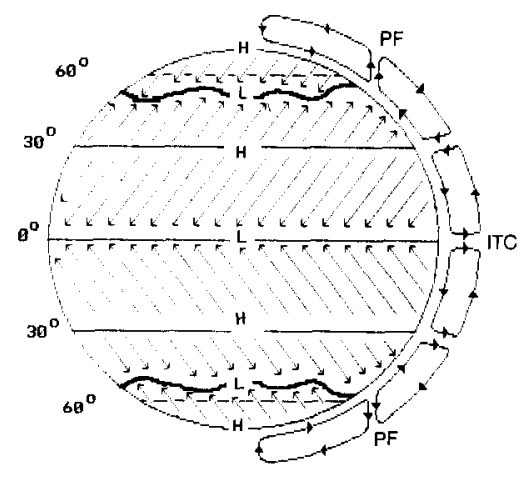

annual mean

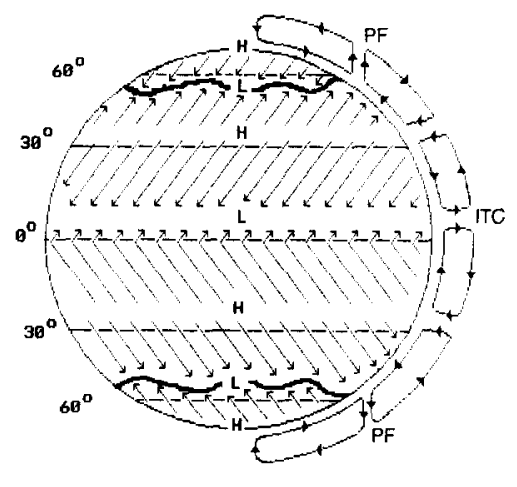

July

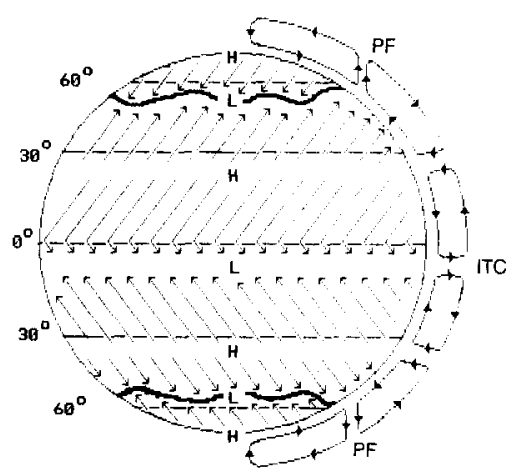

January

Fig. 9. Idealized present-day global surface atmospheric circulation: annual mean; July; January. ITC = Inter-Tropical Convergence; $P F=$ Polar Front; $H=$ high pressure; $L=$ low pressure. 


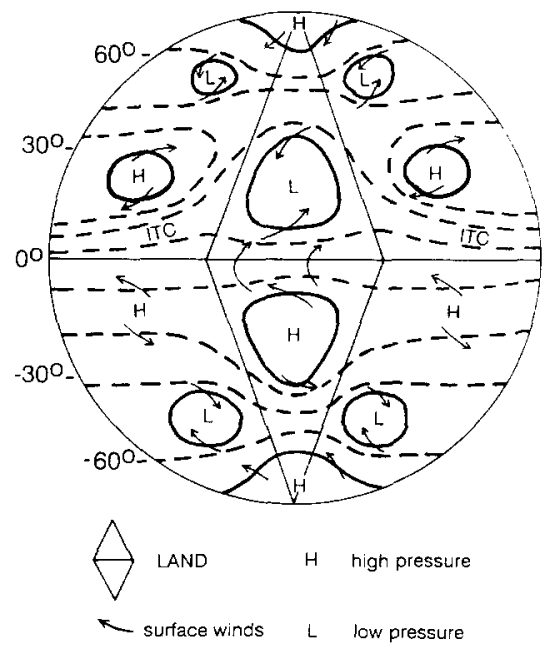

Fig. 10. Surface atmospheric circulation of northern summer given for a hypothetic continent (for explanation see text; modified after Barron, 1985b).

and difficult to calculate, influence the atmospheric circulations. Balance requirements must be fulfilled for the mass transport in the atmosphere and for the exchange of the angular momentum between surface and atmosphere. Besides the land/sea distribution the topography of land, especially the configuration and altitude of mountain chains, influences frictional torques. Additionally, the jet streams, which flow in the upper troposphere between 8 and $12 \mathrm{~km}$ altitude, also play an important role in the atmospheric energy transfer and mass balance. So far their origin is largely unknown and their distribution in part very irregular.

Detailed mathematical palaeoclimatic models are only available for Permian/Triassic, and for mid-Cretaceous and younger ages (e.g. Barron, 1985b, c; Saltzman, 1985; Glancy et al., 1986; Barron et al., 1989; Crowly et al., 1989; Kutzbach and Gallimore, 1989), and even those suffer limitations by unknown or uncertain parameters within the atmospheric circulation system and by the simplifications necessary to treat this complex system mathematically.

For the Phanerozoic conceptual models with a reasonably reliable approach to atmospheric circulation have been proposed by Parrish (1982) and Parrish and Curtis (1982). Based on the same principles, Scotese and Summerhayes (1986) produced preliminary computer-aided palaeoclimatic maps for the Mesozoic and Cenozoic, which correspond to those of Parrish and Curtis (1982). Both assume that the basic structure of the present-day circulation pattern (Fig. 9) was the same in the past. The crucial point, however, is that the present-day polar high-pressure cells are a result of glaciation. The high polar albedo $(\geqslant 0.7)$ causes perennial temperature inversion and a negative lapse rate with very low surface temperatures and increasing values with height, respectively (Barry and Chorley, 1987). This results in descending circulation and a polar high-pressure cell. But even in the present-day Arctic area the anticyclone is by no means a permanent feature (Barry and
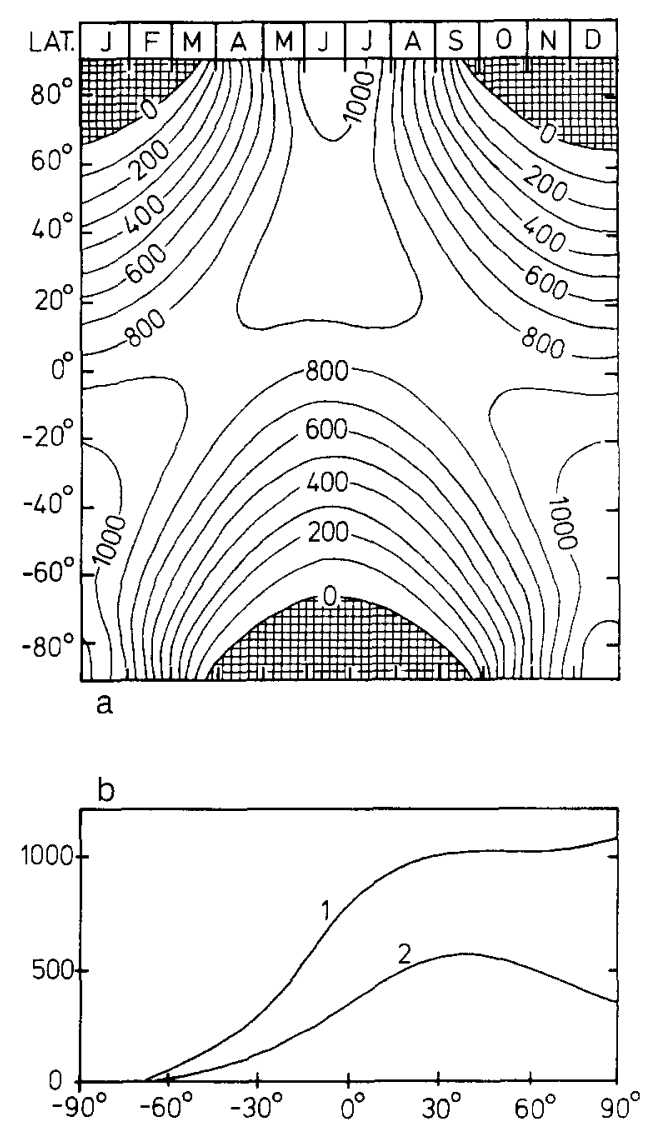

Fig. 11. (a) The variation of solar radiation (cal $\mathrm{cm}^{-2} \mathrm{day}^{-1}$ ) with latitude and season at top of the atmosphere. From mid-May to end of July the maximum energy is supplied to the North Pole (after Fritz, 1951, in Valentine, 1983). (b) Transmission is reduced by absorption and reflection in the atmosphere, but in June and July the North Pole and the Equator still receive approximately the same amount of solar radiation (cal $\mathrm{cm}^{-2}$ day $^{-1}$; after Barry and Chorley, 1987): $I=$ top of atmosphere; 2 = surface. 
Chorley, 1987; Hasse, 1988). Strong and permanent high-pressure cells at the polar areas probably need large-scale glaciation on both poles (as was the case for example in the Pleistocene). During warm periods, like during most of the Mesozoic (e.g. Frakes, 1979; Hallam, 1984, 1985; Barron, 1985a; Parrish and Spicer, 1988a, b), and particularly the late Jurassic, much warmer polar areas are assumed.

At the top of the atmosphere the seasonally accentuated solar radiation supplies maximum energy to the summer hemisphere polar area during mid-May to end of July (Fig. 11). Transmission of the atmosphere in polar areas is remarkably reduced by reflection and absorption of clouds. Nonetheless, the present-day summer pole and the Equator still receive approximately the same amount of radiation on the earth surface in June and July (Fig. 11b), but at the pole most of it is reflected due to the high snow and ice albedo. In snow- and ice-free polar areas the albedo of the earth surface changes drastically from $\geqslant 0.7$ (ice and snow) to 0.3 (badlands) or even down to 0.1-0.2 (forest and polar water bodies; e.g. North and Crowley, 1985; Barry and Chorley, 1987; Ramanathan et al., 1989).

Besides the effect of surface albedo, the effect of cloud cover must be considered when discussing the radiation budget. Unfortunately the cloudiness in general is a largely unknown parameter for ancient times such as for the late Jurassic. Estimates are based on global humid and arid zones and are very crude. Non-glacial high latitudes belong to the humid cool to warm temperate zones with a high precipitation/evaporation rate (e.g. Barry and Chorely, 1987; Barron et al., 1989); from there at least a temporal cloudiness can be inferred. Cloud cover, if it is thick and complete enough, can significantly bar the penetration of radiation. However, it can also operate in reverse, since it retains much of the heat that would otherwise be lost from the earth by outgoing radiation. Additionally, by absorbing certain proportions of energy, clouds may act as temporary thermal reservoirs. In present-day high-latitude areas, the reflected proportion of energy by clouds is smaller than that reflected by snow- and ice-covered surfaces (Barry and Chorley, 1987), although there commonly exists a thick cloud cover, especially over polar oceans (Hasse, 1988; Ramanathan et al., 1989). In general, the role of clouds is a major point of uncertainty, which is also controversially debated in ongoing discussions on the greenhouse effect (e.g. Mitchell et al., 1989; Ramanathan et al., 1989; Raschke, 1989; Slingo, 1989).

Assuming a reduction of the polar surface albedo from $\geqslant 0.7$ to 0.3 and an atmospheric transmission coefficient or a time-averaged cloud cover similar to today's situation, the energy input to polar areas is at least doubled. Warm Arctic summers in the late Jurassic are corroborated by the large continental areas surrounding the small Arctic Sea. Crustal separation in the Canada Basin initially started in the Lower Cretaceous (Rowley and Lottes, 1988, fig. 17; Ziegler, 1988). The nonoceanic Arctic Sea was therefore even smaller than previously thought. Its extent was approximately not more than 3-4 million $\mathrm{km}^{2}$, more or less equal to present-day Barents Sea, Kara Sea, East Siberian Sea and Chukchi Sea, and probably not large enough to create its own marine-influenced atmospheric circulation cell. (Compare the present-day situation of the Mediterranean Sea, Black Sea and Caspian Sea area, which cover almost 4 million $\mathrm{km}^{2}$, but still are strongly influenced by surrounding continents; cf. Parrish et al., 1984.) The similar albedo values of polar water bodies (0.15-0.2; Ramanathan et al., 1989) and land surfaces ( 0.3 badlands, $0.1-0.2$ forest; Barry and Chorley, 1987) additionally weaken the land-sea thermal contrast to some extent. Thus, the Arctic land-sea configuration provided the potential for a weak polar low, which was probably not permanent but prevailing during May to August (Fig. 12). The same is true of the continental South Pole area, which was already situated in Antarctica (Barron et al., 1981; Wilson et al., 1989). The lack of any radiation in winter at the polar areas (Fig. 11) resulted in high-pressure cells analogous to today's situation (Fig. 12), even during globally warm periods (e.g. Sloan and Barron, 1990). A snow cover for some weeks during winter could well have existed in high-latitude land areas but presumably no land- or sea-ice. At the most, local mountain glaciers might have occurred. In general, the late Jurassic atmospheric circulations very 


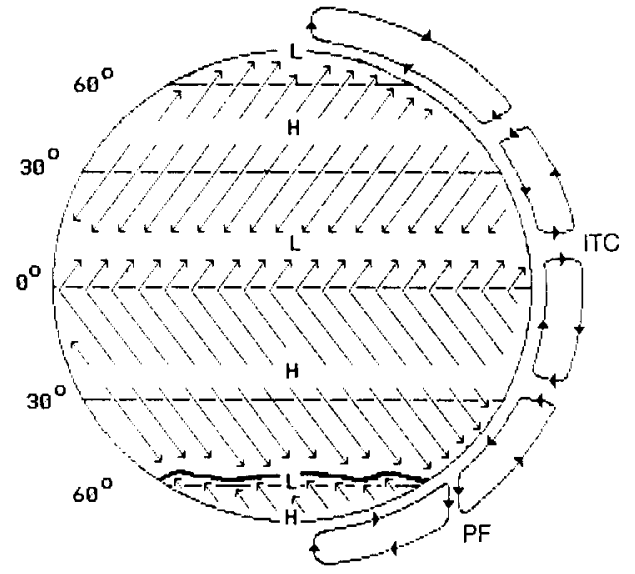

NORTHERN SUMMER

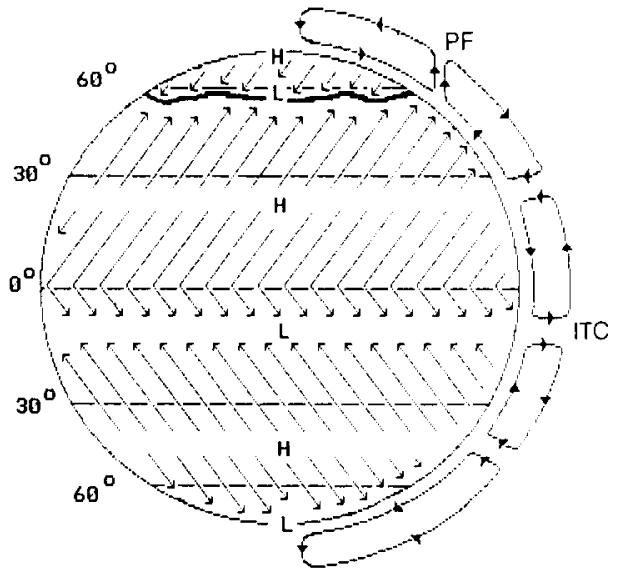

NORTHERN WINTER

Fig. 12. Idealized late Jurassic global surface atmospheric circulation: northern summer; and northern winter. ITC = Inter-Tropical Convergence; $P F=$ Polar Front; $H=$ high pressure: $L=$ low pressure.

likely were ruled by a much stronger summer-towinter asymmetry than today (Figs. 9, 12).

\section{Atmosphere-hydrosphere interaction in the late Jurassic northwestern European basin and the North Atlantic Shelf Sea}

The global circulation pattern deduced from the late Jurassic palaeogeography results in the air pressure maps given in Figs. 13 and 14. The main features are the L-pressure cells over the large continental areas of North America and Asia, whereas the subtropical $\mathrm{H}$-pressure belt reaches from the Central Atlantic to the eastern Tethys. They result in a "monsoonal-type" atmospheric circulation. An additional summer low at the North Pole intensified that circulation.

The northward-flowing winds drove a watercurrent and counter-current system in the North Atlantic Shelf Sea and the Arctic Ocean. The current systems of warm low-latitude surface water $\left(20-30^{\circ} \mathrm{C}\right)$ and relatively cold high-latitude bottom water $\left(10-20^{\circ} \mathrm{C}\right)$ caused a stable water stratification $\left(\delta t \approx 10^{\circ}\right)$ and anoxic bottom conditions which caused the facies development during Kimmeridgian and Tithonian in the North Atlantic Shelf (Fig. 13). The temperature values are supported by isotopic data of Irwin et al. (1977) and Salinas (1984), which are based on coccoliths for surface water and on early diagenetic nodules respectively bivalve molluscs for the bottom water.

In winter the global air pressure situation changed. H-pressure cells over the mid-latitude continents, the typical L-pressures over the oceanic areas at $60^{\circ}$ latitude and a cold high over the Arctic Sea disrupted the monsoonal circulation and the stratified water masses (Fig. 14). During that time re-colonization of the benthic environment took place.

A seasonal reversal of the dominant wind regime and the induced water-current system fits well with the accentuated seasonality of the late Jurassic environments reflected by the microlamination and ecology of the benthic bivalves (see above).

\section{Structural development of the northwest European epeiric basin and the Greenland Norwegian rift system}

An important prerequisite to establish a windinduced water-current/counter-current system in the North Atlantic Shelf Sea was a free and deep enough marine connection. The minimum depth for counteracting currents (e.g. upwelling systems) is generally accepted to be $50 \mathrm{~m}$ (e.g. Parrish et al., 1984).

During the middle and late Jurassic the Central Atlantic developed into a small ocean basin and 


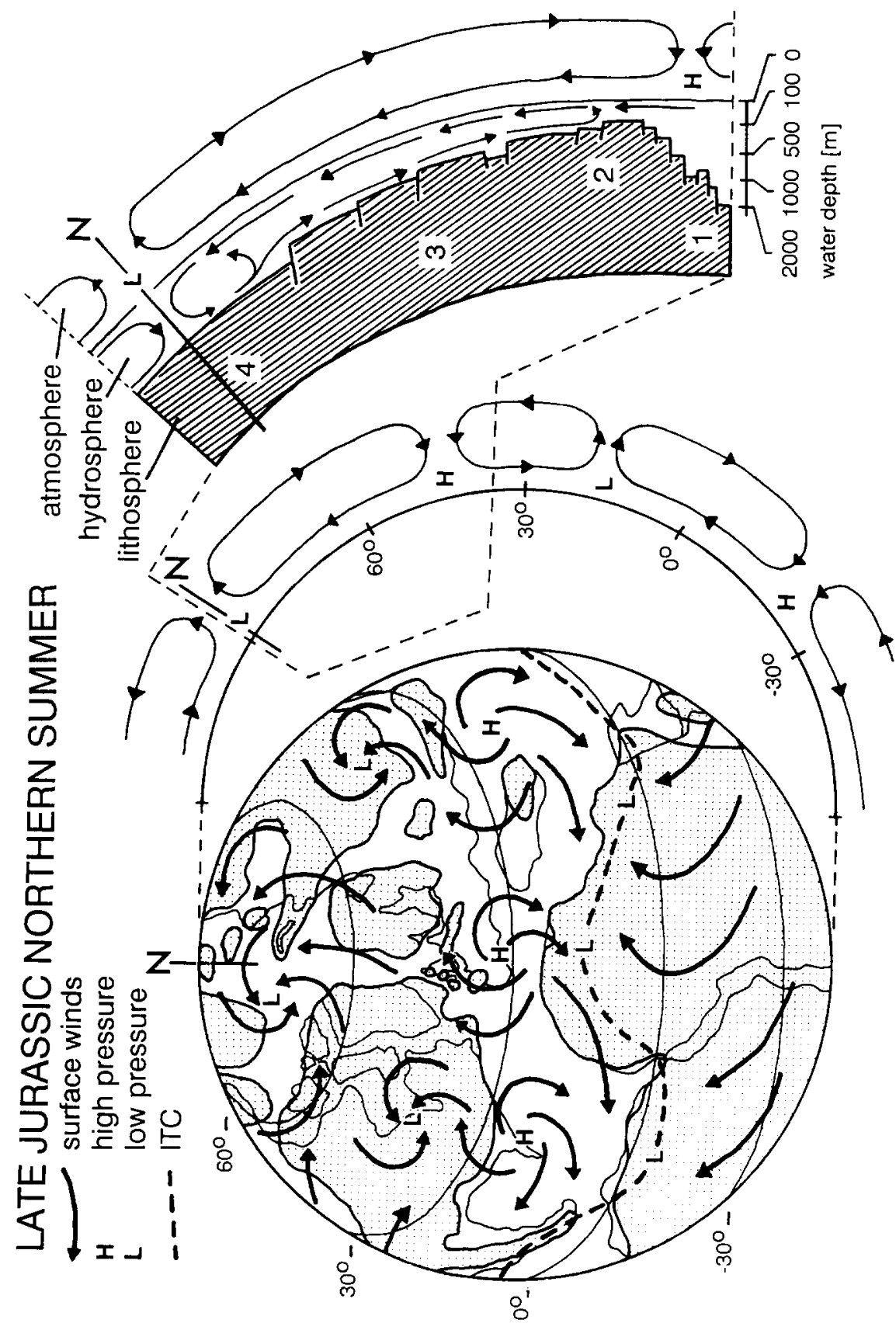

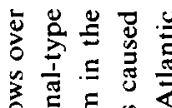

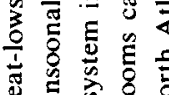

䓃

के

的 9 递

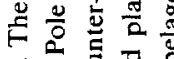

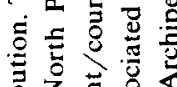

吉完它

宩导量嵒

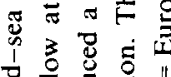

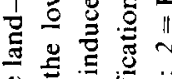

政

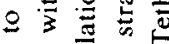

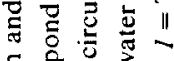

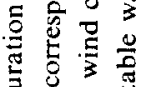

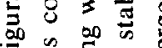

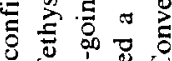

起范要

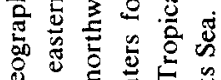

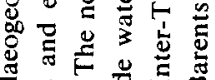

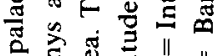

巳 仓

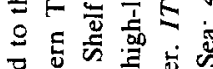

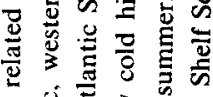

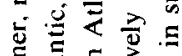

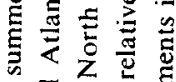

可产焉

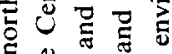

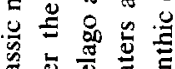

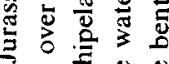

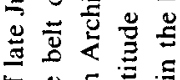

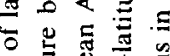

ह

可 ह

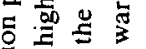

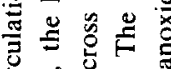

.

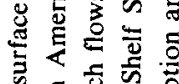

कै

은 z)

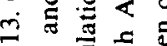

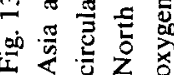




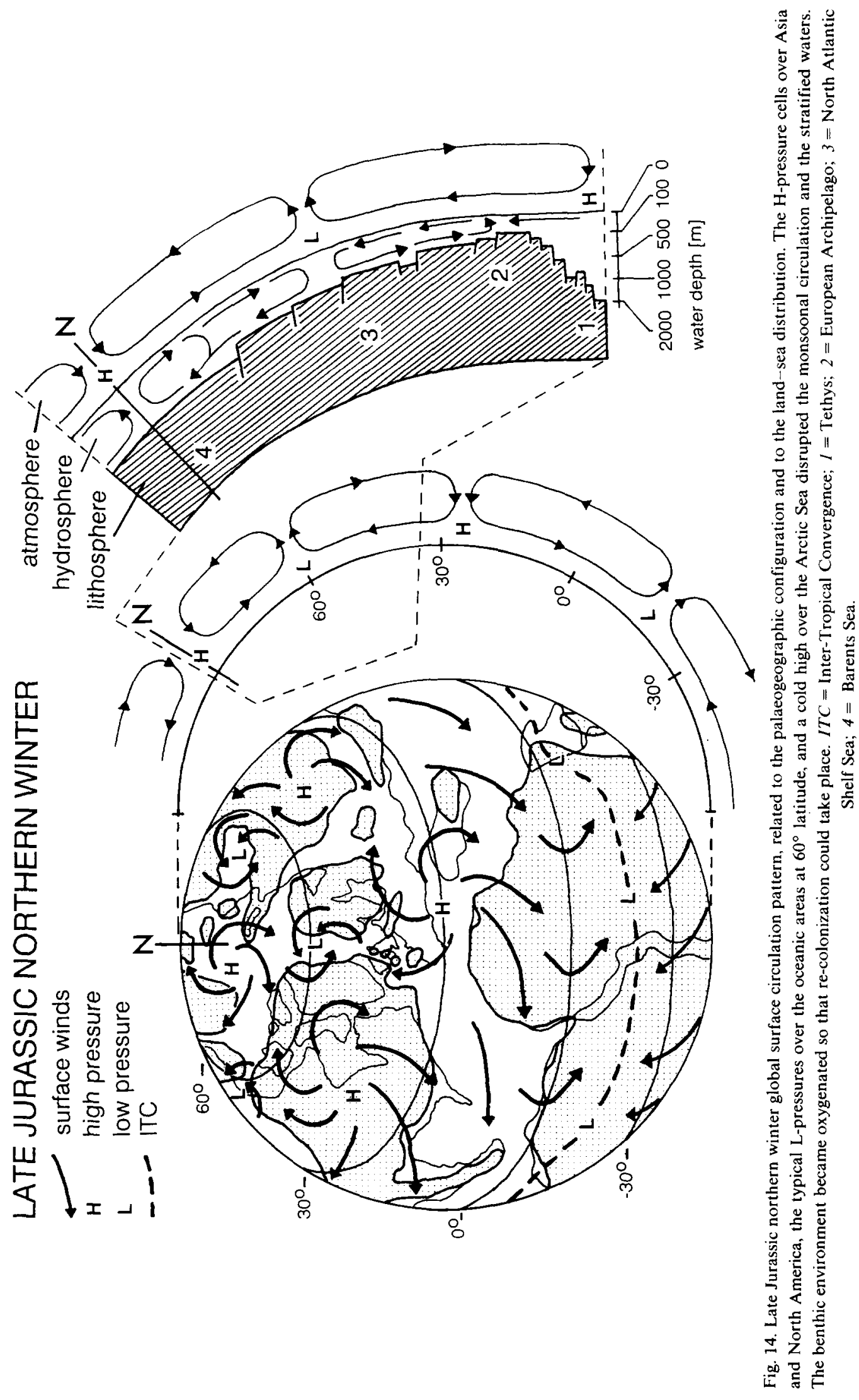


caused re-activation of North Atlantic rift systems in the Newfoundland Rockall area, North Sea and English Channel area, and in the Greenland Norwegian area (Ziegler, 1982, 1988). Crustal extension, continued subsidence and probably intensified spreading in the Central Atlantic caused the major eustatic sea-level rise.

During the Callovian and Oxfordian, the transgression spread over the landmass which existed in the North Sea area as a connecting land-bridge between Laurentia-Greenland and Baltica (Fig. 15 ). At its peak, the late Jurassic transgression inundated most of the land area in the European

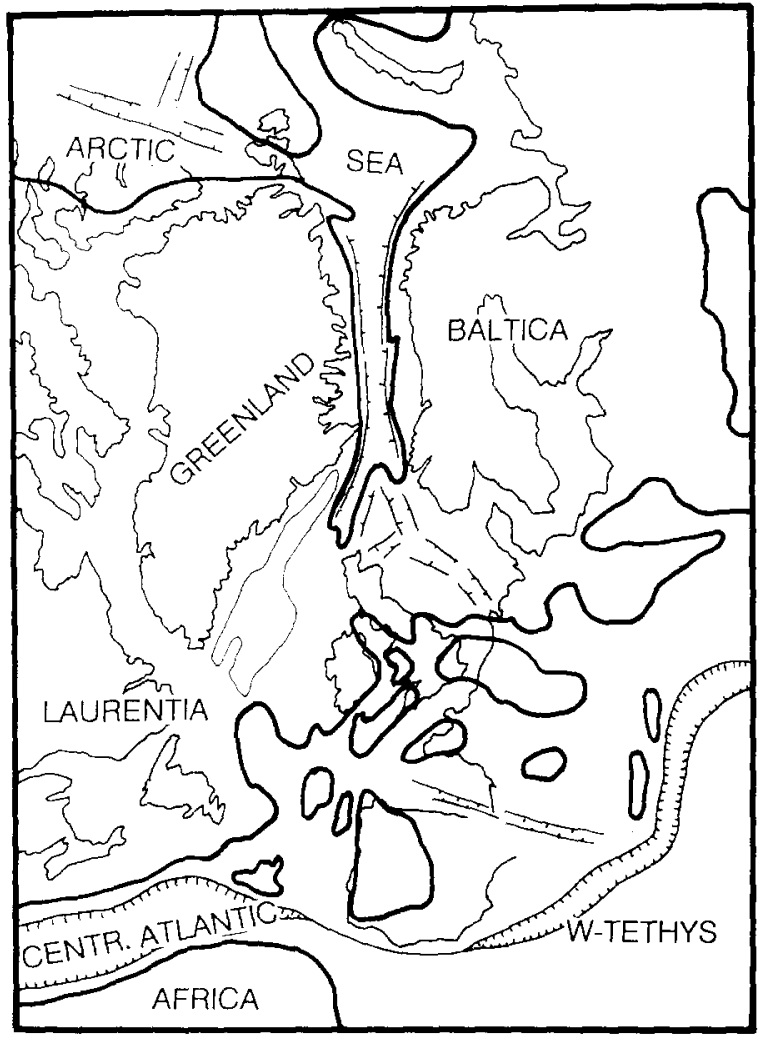

LAND

Fig. 15. Late middle Jurassic (Bathonian/Callovian) palaeogeographic reconstruction of the Arctic, North Atlantic, northern Central Atlantic and western Tethyan Ocean (modified after Ziegler, 1982, 1988; Gage and Doré, 1986; Doré and Gage, 1987). During the Callovian and Oxfordian, the transgression started to spread over the landmass, which existed in the North Sea area as a connecting land-bridge between Laurentia-Greenland and Baltica. The open marine connections to the Arctic Sea were not established before the Kimme ridgian.

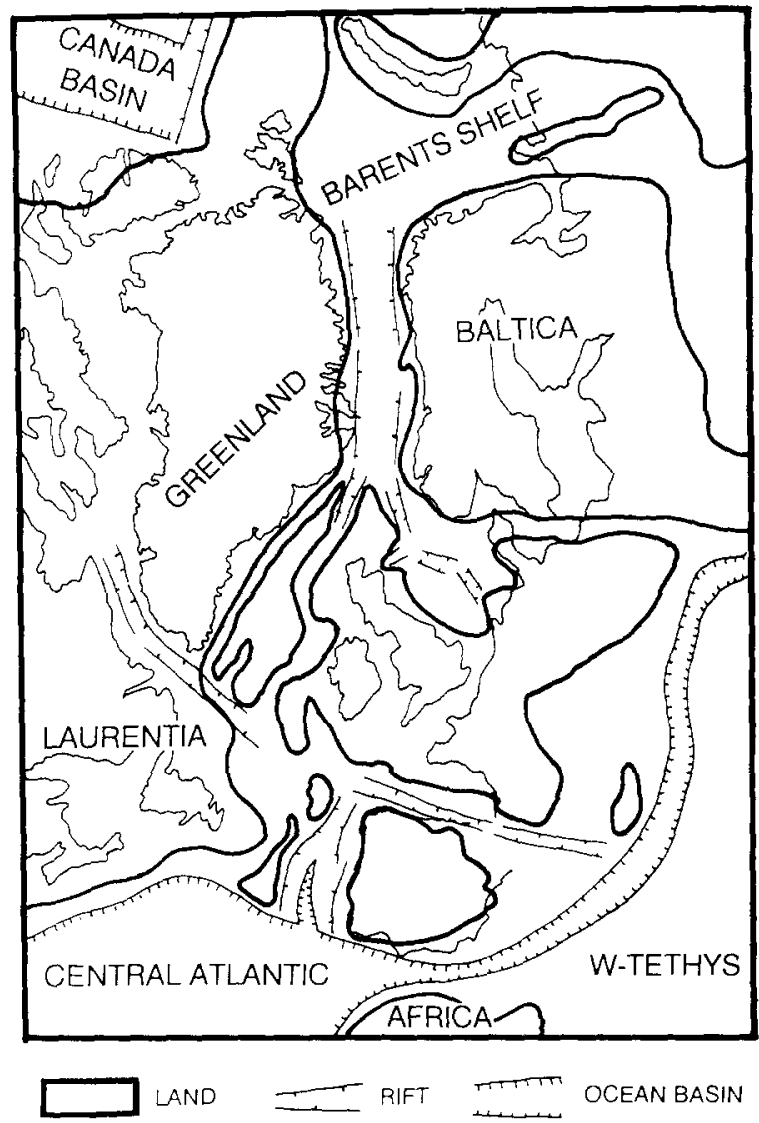

Fig. 16. Early Cretaceous (Berriasian) palaeogeographic reconstruction of the Arctic Sea, North Atlantic, northern Central Atlantic and western Tethyan Ocean (modified after Ziegler, 1982, 1988; Gage and Doré, 1986; Doré and Gage, 1987) Most parts of the northwest European Archipelago again were above sea-level. The water exchange between the Arctic Sea in the north and the Central Atlantic and Tethys Ocean in the south was strongly restricted or interrupted.

Archipelago and established the marine connections between the Arctic Sea, the Central Atlantic and the Tethys Ocean (Fig. 1; Ziegler, 1982, 1988; Gage and Doré, 1986; Doré and Gage, 1987; Hallam, 1988).

In the topmost Jurassic (late Tithonian) the sea level dropped again and was at a relative minimum in the lowest Cretaceous (Berriasian; Fig. 16). Again most parts of the northwest European Archipelago were above sea level. Water exchange between the Arctic Sea in the north and the Central Atlantic and Tethys Ocean in the south was strongly restricted or even interrupted. Obviously the particular situation of the open marine connections in the Kimmeridgian and Lower 
Tithonian formed the framework for the sedimentary processes and the wind-induced water exchange which took place in the northwest European epeiric basin.

\section{Cycle hierarchy in the late Jurassic}

The organic-rich late Jurassic sediments of Dorset, Southern England (i.e. the Kimmeridge Clay, which stratigraphically include the Kimmeridgian and Lower Tithonian, e.g. Cox and Gallois, 1981), probably exhibit the best surface exposures of the inner parts of the late Jurassic northwest European epeiric basin. These sections provide an excellent example of cyclic sedimentation (Fig. 17).

The smallest-scale cycle (A, Fig. 17A) is represented by the microlamination. This is a seasonal cycle, caused by the earth's axial tilt. Individual cycles last one year and represent seasonal alter- nations in climate and in atmospheric and hydrospheric circulation patterns (see above). The alternation of very fine $(0.1 \mathrm{~mm})$ dark coloured, clayrich winter laminae, and fine $(0.1-1 \mathrm{~mm})$ and light coloured coccolith-rich summer laminae indicate a distinct change from an oxygenated benthic environment in winter to anaerobic conditions in summer. Preservation of the microlamination commonly is excellent (Fig. 2), but disturbance and reworking (e.g. by storms) occur (Fig. 4).

The next order of cycles (B, Fig. 17B) is well documented by the facies alternations, which take place within centimetres to metres. An ideal cycle is more or less symmetrical and starts with bioturbate to burrow-mottled sediments, whereby the burrow density decreases upward. Towards the central part of the cycle the microlamination (type A cycles) becomes more and more prominent, indicating maximum oxygen depletion. In the upper part increased burrow density points to a

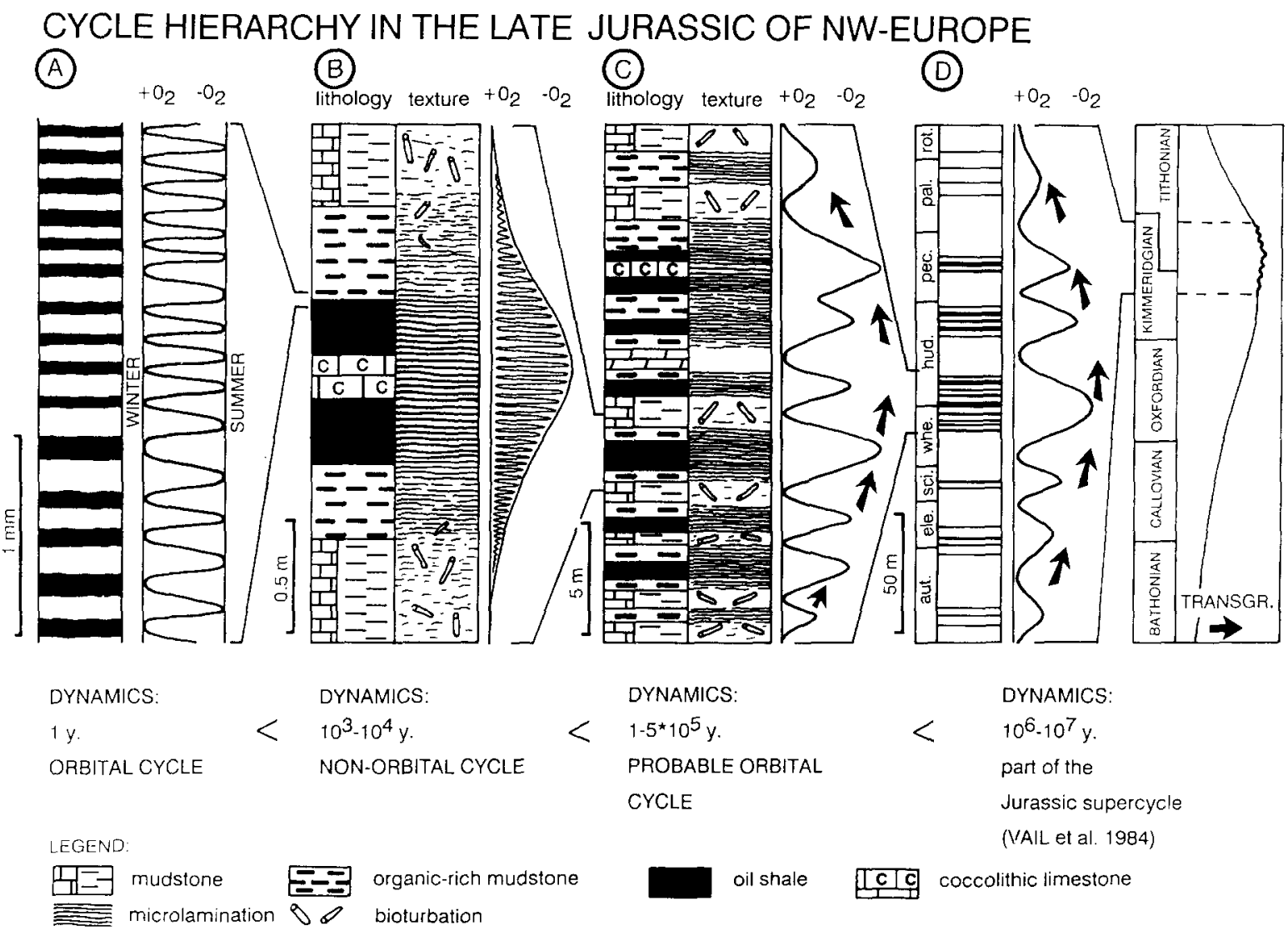

Fig. 17. Hierarchical levels of cycles in the late Jurassic of NW-Europe (for explanation see text; Kimmeridgian ammonite zones: autissiodorensis; elegans; scitulus; wheatleyensis; hudlestoni; pectinatus; pallasioides; rotunda). 
gradual return to oxygenated conditions. The cooccurrence of microlamination and infaunal bivalves found parallel to bedding planes in the poikiloaerobic facies (Figs. 6,7) is limited to the organic-rich mudstones and bituminous shales, respectively.

Commonly these cycles are completely preserved, but in many cases parts of the cycles have been reworked. Distal storm events and/or gentle tectonic movements disrupted the microlamination and produced small-scale slump structures and graded re-sedimentation (Fig. 4; for details see Oschmann, 1985, 1988b; Wignall, 1989). Due to this storm modification, some of the cycles have been altered to hemi-cycles.

The duration of these cycles can be estimated with the help of the microlamination. An averaged arinual sedimentation rate of $0.1 \mathrm{~mm} / \mathrm{yr}$ can be determined by measuring a large number of laminae. The average sedimentation rate is also valid for the burrow-mottled and bioturbate parts of the cycles unless there was storm reworking and lateral sediment transport. The duration of complete cycles varies remarkably and lasts between $5 \times 10^{3}$ and $15 \times 10^{3}$ years. This estimate is thought to be relatively precise. An orbital origin is unlikely, as no periodicity of that magnitude is known so far. Moreover, the cyclicity is too irregular. Similarly, tectonic activities do not explain the symmetry in the cyclic pattern. Climatic oscillations lasting some thousands to ten thousands of years appear to offer the best interpretation. Those variations cause changes of the meteorological pattern. Quasi-permanent high- and low-pressure areas will be weakened, intensified, or laterally displaced for some distance. In analogy, the resulting wind and water current pattern will also be altered. The effect of this on the current/countercurrent system in the North Atlantic Shelf Sea (Fig. 13) is easy to imagine. Formation of highly organic sediments take place under the conditions described there. Air-pressure alternations or displacement, for example of the quasi-permanent high-pressure cell, away from the northern margin of the western Tethys, would also have weakened or even prevented the North Atlantic current and counter-current system. A return to normal oxygen levels would have been the consequence.
The next larger cycles (C, Fig. 17C) consist predominantly of organic carbon-rich strata, to 30 $\mathrm{m}$ thickness (oil shales and coccolithic limestones). They alternate with strata of approximately the same thickness, which are nearly free of organic carbon and consist dominantly of mudstones. The organic carbon-rich parts consist of a composed set of type B cycles. Their thickness increases towards the middle part of the cycle, indicating maximum oxygen deficiency. Again the microlamination and the averaged annual sedimentation rate (see type B cycles) provides a tool to estimate the periodicity, which apparently lasted between $1 \times 10^{5}$ years for the smallest and $5 \times 10^{5}$ years for the largest cycle.

This cyclicity is probably due to small-scale transgressions and regressions, and resembles the third-order and smaller cycles of Vail et al. (1984) and Haq et al. (1987). Short-term sea-level changes strongly influenced the current/counter-current system in the North Atlantic Shelf Sea. At times of high sea-level stands the situation was as described above (Fig. 13). When the sea-level stand was low, the currents could not pass each other and bottom and surface water became mixed. This prevented temperature stratification and stagnant bottom conditions.

The origin of the trans- and regressive cycles is not completely known. Their duration resembles that of cycles caused by the eccentricity of the earth's orbit, which has a primary period of 1.06 $\times 10^{5}$ and a secondary one of $4.13 \times 10^{5}$ years (e.g. House, 1985, 1986; Imbrie, 1985). However, the evaluation of time is not accurate enough and must be considered as an order of magnitude only. In addition, the smaller cycles caused by the earth's orbital geometry, obliquity $\left(4.1 \times 10^{4} \mathrm{yr}\right.$. $)$ and precession $\left(2.3 \times 10^{4}\right.$ yr. and $1.9 \times 10^{4} \mathrm{yr}$. $)$, which correspond with the eccentricity, cannot be recognized in the type B cycles (see above).

Although there is some evidence of an orbitalforced origin, also a non-orbital control, such as variations in subsidence rate and spreading activity, climatic variations, or a combination of several factors must be taken into account as possible causes for eustatic sea-level changes.

The cycle with the longest period (D, Fig. 17D) was the late Jurassic eustatic sea-level rise. It 
started in the Bathonian, was at its peak in the Kimmeridgian and Lower Tithonian, and ended in the early Cretaceous (Vail et al., 1984; Haq et al., 1987; Hallam, 1988). Its duration was several tens of million years (Harland et al., 1982; Vail et al., 1984; Kent and Gradstein, 1985). Establishment of the marine connections between the Arctic Sea, the Central Atlantic and the Tethys Ocean at peak transgression in the Kimmeridgian and lower Tithonian formed the framework for the lowerorder cycles (Figs. 1, 15 and 16; Ziegler, 1982, 1988; Gage and Doré, 1986; Doré and Gage, 1987; Hallam, 1988).

\section{Conclusions}

(1) In the late Jurassic (Kimmeridgian and Tithonian) the whole depositional basin of the northwest European Archipelago and the Norwegian Greenland Sea Area underwent the same depositional history.

(2) The fine-grained microlaminated sediments, which are widespread in the whole area, were deposited in an oxygen-controlled environment.

(3) Despite the widespread occurrence and uniformity of facies, the environment was by no means stable for long periods of time. The particular preservation of articulated infaunal bivalves parallel to bedding planes within microlaminated sediments is explained, in analogy to present-day environments, as the result of seasonal alternations of oxygenated and anaerobic conditions. Life on the sea-floor was bound to an yearly cycle.

(4) The seasonal variation in the oxygen budget reflects the seasonal variation in the atmospheric and hydrospheric circulation patterns. In summer, a "monsoonal-type" circulation drove a warm northward-going surface current and a cold bottom-water counter-current, resulting in a stratified water column. Phytoplankton-blooms in surface waters caused oxygen consumption in the benthic environment. During winter, a predominantly zonal atmospheric circulation disrupted the stratified waters. The benthic environment returned to oxygenated conditions.

(5) Superimposed to this one-year orbital-forced cycle (type A) three more hierarchical levels of cycles occur. They are well documented in the sedimentary record, and have periodicities of several thousand to several million years.

(6) The non-orbital type B cycles probably were caused by air-pressure changes and/or lateral displacements of long-term stable, quasi-permanent pressure cells. They lasted $5 \times 10^{3}$ to $15 \times 10^{3}$ years.

(7) The type $\mathrm{C}$ cycles refer to small-scale sealevel changes and last between $1 \times 10^{5}$ and $5 \times 10^{5}$ years. The may have been caused by eccentricity of earth's orbit.

(8) The longest cycle is the late Jurassic transgression, which established open marine connections between Central Atlantic, western Tethys and the Arctic Sea.

\section{Acknowledgements}

I am grateful to Martin Aberhan and Franz T. Fürsich (both Würzburg) for stimulating discussions and for reviewing the manuscript. Tom Aigner (Rijswijk), Reinhold Leinfelder (Stuttgart) and Judith T. Parrish (Tucson) additionally reviewed the manuscript. Their very helpful comments are gratefully acknowledged.

\section{References}

Arthur, M.A., Dean, W.E. and Stow, D.A.V., 1984. Models for the deposition of Mesozoic-Cenozoic fine-grained organic-carbon-rich sediments in the deep sea. In: D.A. Stow and D.J.W. Piper (Editors), Fine-grained Sediments: Deep Water Processes and Facies. Blackwell, London, pp. $527-560$.

Barron, E.J., 1985a. A warm, equable Cretaceous: the nature of the problem. Earth-Sci. Rev., 19: 305-338.

Barron, E.J., 1985b. Mumerical climate modeling, a frontier in petroleum source rock prediction: result based on Cretaceous simulations. Am. Assoc. Pet. Geol. Bull., 69: 448-459.

Barron, E.J., 1985c. Climate models: applications for the prePleistocene. In: A.D. Hecht (Editor), Paleoclimate Analysis and Modeling. Wiley and Sons, New York, N.Y., pp. 397-421.

Barron, E.J., Harrison, C.G., Sloan, J.L., II and Hay, W.W., 1981. Paleogeography, 180 million years ago to the present. Eclogae Geol. Helv., 73: 443-470.

Barron, E.J., Hay, W.W. and Thompson, S., 1989. The hydrologic cycle: a major variable during earth history. Palaeogeogr., Palaeoclimatol., Palaeoecol. (Global Planet. Change Sect.), 75: 157-174. 
Barry, R.G. and Chorley, R.J., 1987. Atmosphere, Weather and Climate. Methuen, London, 460 pp.

Bassett, M.G., 1990. Zone fossils. In: D.E.G. Briggs and P.R. Crowther (Editors), Palaeobiology-A Synthesis. Blackwell, Oxford, pp. 466-467.

Byers, C.W., 1977. Biofacies pattern in euxinic basins: a general model. In: H.E. Cook and P. Enos (Editors), Deepwater Carbonate Environments. Soc. Econ. Paleontol. Mineral., Spec. Publ., 25: 5-17.

Cary, S.C., Fisher, C.R. and Felbeck, H., 1988. Mussel growth supported by methane as sole carbon and energy source. Science, 240: 78-80.

Cornford, C., 1986. Source rocks and hydrocarbons of the Worth Sea. In: K.W. Glennie (Editor), Introduction to the Petroleum Geology of the North Sea. Blackwell. Oxford, pp. 197-236.

Cox, B.M. and Gallois, R.W., 1981. The stratigraphy of the Kimmeridge Clay of Dorset type area and its correlation with some other Kimmeridgian sequences. Inst. Geol. Sci., 80: $1-33$.

Crowley, T.J., Hyde, W.T. and Short, D.A., 1989. Seasonal cycle variations on the supercontinent of Pangea. Geology, 17: $457-460$

Dethlefsen, V. and Westernhagen, H., 1983. Oxygen deficiency and effects on bottom fauna in the eastern German Bight 1982. Meeresforschung, 30: 42-53.

Doré, A.G. and Gage, M.S., 1987. Crustal alignments and sedimentary domains in the evolution of the North Sea, North-east Atlantic margin and Barents Shelf. In: J. Brooks and K. Gilennie (Editors), Petroleum Geology of North West Europe. Graham and Trotman, London, pp. 11311148.

Frakes, L.A., 1979. Climate throughout Geological Time. Elsevier, Amsterdam, $310 \mathrm{pp}$.

Fürsich, F.T., 1982. Upper Jurassic bivalves from Milne Land, East Greenland. Bull. Gronland Geol. Unders., 144: 126 pp.

Fürsich, F.T., 1984a. Distribution pattern of benthic associations in offshore shelf deposits (Upper Jurassic, Central East Greenland), In: J.-C. Gall (Editor), Paléoécologie, Congrès International, Lyon 1983. Geobios, Mém. Spéc., 8: $75-84$.

Fürsich, F.T., 1984b. Benthic macroinvertebrate associations from boreal Upper Jurassic of Milne Land, central East Greenland. Bull. Grenlands Geol. Unders., 149: 72 pp.

Gage, M.S. and Doré, A. G, 1986. A regional geological perspective of the Norwegian offshore exploration provinces. In: Norwegian Petroleum Society, Habitat of Hydrocarbons on the Norwegian Continental Shelf. Graham and Trotman, London, pp. 21-38.

Glancy, T.J., Jr., Barron, E.J. and Artur, M.A., 1986. An initial study of the sensitivity of modeled Cretaceous climate to cyclical insolation forcing. Paleoceanography, 1: 523-537.

Hallam, A., 1984. Humid and arid zones in the Jurassic and Cretaceous. Palaeogeogr., Palaeoclimatol., Palaeoecol., 47: 195- 223.
Hallam. A., 1985. A review of mesozoic climates. J. Geol. Soc. London, 142: 433-445.

Hallam, A., 1988. A reevaluation of the Jurassic eustacy in the light of new data and the revised EXXON curve. In: C.K. Wilgus, B.S. Hastings, H. Posamentier, J. Van Wagoner, C.A. Ross and C.G.S.C. Kendall (Editors), Sea-level Changes-An Integrated Approach. Soc. Econ. Paleontol. Mineral., Spec. Publ., 25: 261-273.

Haq, B.U., Hardenbol, J. and Vail, P.R., 1987, Chronology of fluctuating sea levels since the Triassic. Science, 235: 11561166.

Harland, W.B., Cox, A.V.. Llewellyn. P.G., Pickton, C.A., Smith, A.G. and Walters, R., 1982. A Geological Time Scale. Cambridge University Press, Cambridge, 131 pp.

Hasse, L., 1988. Klima und Wetter des Europäischen Nordmeeres. Geowissenschaften, 6: 235-241.

House, M.R., 1985. A new approach to an absolute time-scale from measurements of orbital cycles and sedimentary microrythms. Mature, 315: 721-725.

House, M.R., 1986. Towards a more precise time scale for geological events. In: R.W. Wesbitt and J. Nicol (Editors), Geology in the Real World-The Kingsley Dunham Volume. Institute of Mining and Metallurgy, London, pp. 197-206.

Imbrie, J., 1985. A theoretical framework for Pleistocene ice ages. J. Geol. Soc. London, 142: 417-432.

Irwin, H., Curtis, C.D. and Coleman, M., 1977. Isotopic evidence for source of diagenetic carbonates formed during burial of organic rich sediments. Nature, 269: 209-213.

Kammer, T. W, Brett, C.E., Boardmen, D.R., II and Mapes, R.G., 1986. Ecologic stability of the dysaerobic biofacies during the Late Paleozoic. Lethaia, 19: 109-120.

Kent, D.V. and Gradstein, F.M., 1985. A Cretaceous and Jurassic geochronology. Geol. Soc. Am. Bull., 97: 14191427.

Kutzbach, J.E. and Gallimore, R.G., 1989. Pangean climates: megamonsoons of the megacointinent. J. Geophys. Res. 94: 3341-3357.

Mitchell, J.F.B., Senior, C.A. and Ingram, W.J., 1989. $\mathrm{CO}_{2}$ and climate: a missing feedback? Nature, 341: 132-134.

North, G.R. and Crowley, T.J., 1985. Application of a seasonal climate model to Cenozoic glaciation. J. Geol. Soc. London, 142: 475-482.

Oschmann, W., 1985. Faziesentwicklung und Provincialismus in Nordfrankreich und Südengland zur Zeit des obersten Jura (Oberkimmeridge und Portland). Münchner Geowiss. Abh., A, pp. 1-119.

Oschmann, W., 1988a. Upper Kimmeridgian and Portlandian marine macrobenthic associations from southern England and northern France. Facies, 18: 49-84.

Oschmann, W., 1988b. Kimmeridge Clay sedimentation-a new cyclic model. Palaeogeogr., Palaeoclimatol., Palaeoecol., 65: 217-251.

Oschmann. W., 1990. Anaerobic-poikiloaerobic-aerobic: a new zonation for modern and ancient neritic redox facies. In: G. Einsele, W. Ricken and A. Seilacher (Editors), 
Events and Cycles in Stratigraphy. Springer-Verlag, Heidelberg (in press)

Oschmann, W., 1991. Distribution, dynamics and palaeoecology of Kimmeridgian (Upper Jurassic) shelf anoxia in Western Europe. Geol. Soc. London Spec. Publ. (in press).

Parrish, J.T., 1982. Upwelling and petroleum source beds, with reference to the paleozoic. Bull. Am. Assoc. Pet. Geol., 66: $750-774$

Parrish, J.T. and Barron, E.J., 1986. Paleoclimates and economic geology. Soc. Econ. Paleont. Mineral., Short Course, 18: $162 \mathrm{pp}$

Parrish, J.T. and Curtis, E.L., 1982. Atmosphere circulation, upwelling and organic-rich rocks in the Mesozoic and Cenozoic eras. Palaeogeogr., Palaeoclimatol., Palaeoecol., 40: $31-66$.

Parrish, J.T. and Spicer, R.A., 1988a. Middle Cretaceous wood from the Wanusuk group, central north slope, Alaska. Palaeontology, 31: 19-34.

Parrish, J.T. and Spicer, R.A., 1988b. Late Cretaceous terrestrial vegetation: a near polar temperature curve. Geology, 16: 22-25.

Parrish, J.T., Gaynor, G.C., Swift, D.J.P., 1984. Circulation in the Cretaceous Western Interior Seaway of North America, a review. Can. Soc. Pet. Geol., Mem., 9: 221-231.

Rachor, E., 1982. Indikatorkarten für die Umweltbelastung im Meer. Decheniana, Beih., 26: 128-137.

Ramanathan, V., Barkstrom, B.R. and Harrison, E.F., 1989. Climate and the earth's radiation budget. Phys. Today, 42: 22-32.

Raschke, B., 1989. Der Strahlungshaushalt der Erde. Naturwissenschaften, 76: 351-357.

Requejo. A.G., Hollywood, J. and Halpern, H.I., 1989. Recognition and source correlation of migrated hydrocarbons in Upper Jurassic Hareelv Formation, Jameson Land, East Greenland. Am. Assoc. Pet. Geol. Bull., 73: 1065-1088.

Rhoads, D.C. and Morse, I.W., 1971. Evolutionary and ecological significance of oxygen-deficient marine basin. Lethaia, 4: 414-428.

Rowley, D.B. and Lottes, A., 1988. Plate-kinematic reconstructions of the North Atlantic and Arctic: Late Jurassic to present. Tectonophysics, 155: 73-120.

Salinas, I., 1984. Thesis, Geological Institute, University of Copenhagen, Copenhagen (unpublished).

Saltzman, B., 1985. Paleoclimate modeling. In: A.D. Hecht (Editor), Paleoclimate Analysis and Modeling. Wiley and Sons, New York, N.Y., pp. 341-396.

Sastry, A.N., 1979. Pelecipoda (excluding oysters). In: A.C. Giese and J.S. Pears (Editors), Reproduction of Marine Invertebrates, 5. Academic Press, New York, N.Y., pp. 113-292.

Savrda, C.E. and Bottjer, D.J., 1987. The exaerobic zone, a new oxygen deficient marine biofacies. Nature, 327: 54-56.

Savrda, C.E., Bottjer, D.J. and Grosline, D.S., 1984. Developments of an oxygen-deficient marine biofacies model: evi- dence from Santa Monica, San Pedro and Santa Barbara basins, California continental borderland. Bull. Am. Assoc. Pet. Geol. 68: 1178-1192.

Schwarzacher, W., 1989. Milankovitch cycles and measurement of time. Tera Nova, 1: 405-408.

Scotchman, I.C., 1989. Diagenesis of the Kimmeridge Clay Formation, onshore UK. J. Geol. Soc. London, 146: 285303.

Scotese, C.R. and Summerhayes, C.P., 1986. Computer model of paleoclimate predicts coastal upwelling in the Mesozoic and Cenozoic. Geobyte, Summer 1956, pp. 28-42.

Seilacher, A., 1990. Abberations in Bivalve evolution related to photo- and chemosymbiosis. Hist. Biol., 3: 289-311.

Slingo, T, 1989. Wetter clouds dampen global greenhouse warming. Nature, 341: 104.

Sloan, L.C. and Barron, E.J., 1990. "Equable" climates during earth history? Geology, 18: 489-492.

Steimle, F.W. and Sindermann, C.J., 1978. Review of oxygen depletion and associated mass mortalities of shellfish in the Middle Atlantic Bight in 1976. Mar. Fish. Rev. 40: 17-26.

Swanson, E.L., Sindermann, C.J. and Han, G., 1979. Oxygen depletion and the future: an evaluation. In: R.L. Swanson and C.J. Sindermann (Editors), Oxygen Depletion and Associated Benthic Mortalities in New York Bight, 1976. Natl. Oceanogr. Atm. Adm., Prof. Pap., 11: 335-345.

Taylor, F.J., Taylor, N.J. and Walsby, J.R., 1985. A bloom of the planktonic Diatom, Cerataulina pelagica, off the coast of Northeastern New Zealand in 19B3, and its contribution to an associated mortality of fish and benthic fauna. Int. Rev. Ges. Hydrobiol., 70: 773-795.

Thompson, J., Mullins, H.T., Mewton, C.A. and Vercoutere, T.L., 1985. Alternative biofacies model for dysaerobic communities. Lethaia, 18: 167-179.

Tyson, R.V., Wilson, R.C. and Downie, C., 1979. A stratified water column environmental model for the type Kimmeridge Clay. Nature, 277: 377-380.

Vail, P.R., Hardenbol, J. and Todd, R.G., 1984. Jurassic unconformities, chronostratigraphy, and sea-level changes. In: Seismic Stratigraphy and Biostratigraphy. Am. Assoc. Pet. Geol., Mem., 36: 129-144.

Valentine, J.W., 1983. Seasonality: effects in marine benthic communities. In: M.J.S. Tevesz and P.L. McCall (Editors), Biotic Interaction in Recent and Fossil Benthic Communities. Plenum Press, New York, N.Y., pp. 121-156.

Westernhagen, H. and Dethlefsen, V., 1983. North Sea oxygen deficiency 1982 and its effects on bottom fauna. Ambio, 12: $264-266$.

Wignall, P.B., 1989. Sedimentary dynamics of the Kimmeridge Clay: tempestites and earthquakes. J. Geol. Soc. London, 146: $273-284$.

Wignall, P.B. and Myers, K.J., 1988. Interpreting benthic oxygen levels in mudrocks: a new approach. Geology, 16 : 452-455.

Wilson, K.W., Rosol, M.J., Hay, M.W. and Harrison, C.G.A., 
1989. New model for the tectonic history of West Antarctica: a reappraisal of the fit of Antarctica in Gondwana. Eclogae Geol. Helv., 82: 1-35.

Wilson, R.C.L., 1980. Changing Sea-levels: A Jurassic Case Study. Open University Press, Milton Keynes, pp. 49-65.
Ziegler, P.A., 1982. Geological Atlas of Western and Central Europe. Elsevier, Amsterdam, 130 pp.

Ziegler, P.A., 1988. Evolution of the Arctic-North Atlantic and the Western Tethys. Am. Assoc. Pet. Geol., Mem., 43: viii +197 pp. 